\title{
Transcriptional Activation and Repression of Cell Cycle Regulatory Molecules by Trichostatin A
}

\author{
Jong-Soo Baek ${ }^{1}$, Hee-Kyung Lee', Young-Su Cho ${ }^{2}$, Sung-Young Kim ${ }^{3}$, Kwan-Kyu Park and \\ Young-Chae Chang *
}

Department of Pathology, Catholic University of Daegu School of Medicine, Daegu, 705-034, Korea

${ }^{1}$ Department of Dentistry, College of Medicine, Yeungnam University, Daegu 705-717, Korea

${ }^{2}$ Department of Biotechnology, College of Natural Resources and Life Science, Dong-A University, Busan 604714, Korea

${ }^{3}$ Department of Food Science, Andong Science College 496, kyo-ri, Seohu-myon, Andong, Kyongbuk 760-822, Korea

Received October 28, 2005 /Accepted December 13, 2005

\begin{abstract}
The dihydrofolate reductase $(d h f r)$ promoter contains cis-acting element for the transcription factors $\mathrm{Sp} 1$ and E2F. Transcription of dhfr gene shows maximal activity during the G1/S phase of cell cycle. The member of the Sp1 transcriptional factor family can act as both negative and positive regulators of gene expression. There was a report that Sp1-Rb and E2F4-p130 complexes cooperate to establish stable repression of dhfr gene expression in $\mathrm{CHOC} 400$ cells. Here, we examined the role of HDAC in dhfr, cyclin E, and cyclin A gene regulation using the histone deacetylation inhibitor, trichostatin A (TSA) in U2OS and C33A cells, a $\mathrm{Rb}$-positive human osteosarcoma cell line, and a Rb-negative cervical carcinoma cell line, respectively. When the dhfr promoter constructs were applied in U2OS cells, TSA markedly stimulated over 14-fold of $d h f r$ promoter activity through $d h f r-S p 1$ sites by the deletion of an E2F element. In contrast, the deletion of dhfr-Sp1 binding sites completely abolished promoter stimulation by TSA. The dhfr promoter activity including $d h f r$-Sp1 sites increased only 2 -fold in C33A cells. Promoter activity containing only $d h f r-E 2 F$ site did not have much effect by the treatment of TSA in both U2OS and C33A cells. On the other hand, treatment with TSA induced significantly mRNA expression of dhfr and cyclin E, whereas levels of cyclin A decreased in U2OS cells, but had no effect in C33A cells. These results indicate that TSA have contradictory effect, activation of dhfr and cyclin E genes on G1 phase, and down-regulation of cyclin A on G2 phase through transcriptional regulation in U2OS cells.
\end{abstract}

Key words - Trichostatin A, Sp1, E2F, Osteosarcoma, Cervical dhfr

There is a close association between histone deacetylase (HDAC) activity and repression of transcription in tumors, therefore the inhibitors of HDAC are emerging as an new important class of potential anticancer agents [20,24,35,41]. Trichostatin A (TSA) is a potent specific inhibitor of HDAC activity through the mechanism that involves $\mathrm{Zn}^{+}$ion chelation [13]. In general, HDAC is inhibited by accumulation of acetylated histone protein. In the past several years, studies of HDAC inhibitor have shown that TSA induces cell cycle arrest, differentiation, and apoptotic cell death in a number of cancers $[9,12,34]$. However, inhibition of HDAC activity that leads to cell cycle arrest and differentiation is an area of intense investigation.

Histones are core proteins of nucleosomes and acetylation of nuclear histones is regulated by histone acetyltransferase and $\operatorname{HDAC}[23,37]$. Binding of transcriptional factors to DNA

*Corresponding author

Tel : +82-53-650-4848, Fax : +82-53-650-4834

E-mail : ycchang@cu.ac.kr recruits histone acetyltransferase proteins that lead to the acetylation of core histone, enhance nucleosomal relaxation, and subsequently induce transcription [28]. On the other hand, several transcriptional factors, such as CCAAT binding factor (CBF) [21], hormone-dependent nuclear receptors [15], and Mad [22] can bind to HDAC, which stabilize nucleosomal structure and represses transcription [8]. Thus, histone acetylation is known to be associated with transcriptional activity in eukaryotic cells. For example, HDAC inhibitors induce the expression of cyclin-dependent kinase inhibitor p21WAF1/ Cip1 $[27,30,17,14]$, which causes cell growth arrest in various tumor cell lines. Dihydrofolate reductase (dhfr) catalyzes the synthesis of purines, thymidylate and glycine, therefore it is necessary for the replication of DNA in the $S$ phase of the cell cycle. Although transcription of the dhfr gene increases dramatically at the G1/S phase boundary $[10,11,31]$, dhfr mRNA is present throughout the cell cycle $[16,31]$, accounting for a steadily increasing dhfr enzymic activity [19]. Considerable efforts have been made to identify the constitutive factors that 
control the dhfr promoter, and the factors that confer cell-cycle regulation on this gene. In this regard, the ahfr promoter contains transcriptional binding site for the transcription factors $\mathrm{Sp} 1$ and E2F. It has been demonstrated that distinct GC boxes, responsible for Sp1 binding, direct transcription at two principal transcriptional initiation sites in rodents $[3,7]$. Only the most proximal GC box, at least in hamster cells, is needed to correctly initiate transcription at the major proximal site. Deletion of this GC box abolishes transcription of the dhfr gene [6], despite the presence of the E2F-binding element just downstream of the major transcriptional start. It has also been shown that E2F from human cells, either in nuclear extracts or purified, is able to binds to its recognition sequence in the murine [26] and hamster [2,36] dhfr genes, and that the E2F site is required for growth regulation $[4,25]$. Transcription of the dhfr is low in quiescent cells and is activated after pRb family protein phosphorylation during growth stimulation [38,39]. In some settings the overlapping dhfr E2F sites alone are sufficient for induction of transcription after the G1 restriction point. Other studies suggested that the reiterated Sp1 sites, which are required for selection of transcriptional start sites and which regulate basal levels of expression, contribute to activation of dhfr during growth stimulation [1,18,29].

It was demonstrated that repression of dhfr gene expression by E2F and Sp1 in the presence of low serum can be temporarily alleviated by TSA [5]. HDAC1 was recruited to the dhfr gene promoter during withdrawal from the cell cycle, and they showed that complexes of Sp1/pRB and E2F4/p130 act together over time to mediate repression of $d h f r$ gene expression in CHOC400 cells .

In this study, we investigated the potential function between cell cycle regulatory molecules and HDAC as transcriptional repressor during the growth arrest in retinoblastoma (Rb)-positive human osteosarcoma, U2OS and Rb-negative human cervical carcinoma, C33A cells. Using the dhfr promoter as a model system of the transcriptional regulation, we have shown that $\mathrm{HDAC1}$ can mediate transcriptional repression through the Sp1 binding site in ihfr promoter in both cells. Although it is not the related proteins of the whole cell cycle, the results of this study indicate that TSA causes an up-regulation of the gene expression such as G1 function genes, dhfr and cyclin E, but down-regulation of the gene expression of $\mathrm{G}_{2}$ function gene, cyclin $\mathrm{A}$.

\section{Material and methods}

\section{Cell culture}

Human osteosarcoma (U2OS) and human cervical carcinoma (C33A) cells were cultured in Dulbecco' modified Eagle' medium (DMEM) supplemented with $10 \%$ fetal bovine serum (FBS) and antibiotic-antimycotic $(1 \times)$ at $37^{\circ} \mathrm{C}$ under humidified conditions of $95 \%$ air $/ 5 \% \mathrm{CO}_{2}$. Trichostatin A (TSA, Sigma) was added to the culture medium of U2OS, or C33A, in what we define hereafter

Trichostatin A was added to the culture medium at 0, 10, 50 and $100 \mathrm{nM}$ concentrations for $24 \mathrm{~h}$.

\section{Plasmids}

The pGL3-DHFR-WT, the reporter plasmid containing 230 bp of upstream sequence of $d$ hfr promoter was constructed using PCR amplification as previously described [5]. Briefly, the pGL3-DHFR-WT reporter plasmid reporter contains 230 bp of upstream sequence of the dhfr promoter that includes the transcription start site, the overlapping E2F elements, and the Sp1 binding sites (GC boxes I-IV). The pGL3-DHFR-Sp1 luciferase reporter includes nucleotides -230 to -85 , which contain GC boxes I to IV, but not the E2F sites. The pGL3-DHFR-E2F luciferase reporter contains the two overlapping E2F sites alone. The pCMV-Sp1, pCMV-E2F1, pCMV-DP1 and pCMVHDAC-Flag plasmids were kind gift of Dr. P. Farnham [32].

\section{Flow cytometary analysis}

The cell cycle progression of U2OS and C33A cells following TSA treatment was analyzed by flow cytometry. Approximately $2 \times 10^{6}$ cells were trypsinized, collected, and washed with phosphate buffered saline (PBS) containing $2 \%$ FBS. The cells were suspended in $100 \mu \mathrm{l}$ PBS and then $200 \mu \mathrm{l}$ of $95 \%$ ethanol was added to the cells while vortexing. The cells were incubated at $4^{\circ} \mathrm{C}$ for $2 \mathrm{~h}$, washed with PBS, and resuspended with $12.5 \mu \mathrm{g}$ RNase in $250 \mu \mathrm{l}$ of $1.12 \%$ sodium citrate buffer ( $\mathrm{pH} 8.45$ ). Incubation was continued at $37^{\circ} \mathrm{C}$ for 30 min before staining of the cellular DNA with $250 \mu \mathrm{g}$ propidium iodide $(50 \mu \mathrm{g} / \mathrm{ml})$ for $30 \mathrm{~min}$ at room temperature. The stained cells were analyzed on a FACScalibur system (BD Biosciences, Palo Alto, USA) for relative DNA content, based on increased red fluorescence. 


\section{RT-PCR analysis}

Total RNA was extracted with RNAzolB (Life Techology, Grand Island, NY, USA), and suspended in 50 $\mu l$ of Diethyl Pyrocarbonate (DEPC) treated water. For the first strand of cDNA synthesis, $3 \mu \mathrm{g}$ of total RNA was transcribed using an oligo-dT primer (Promega, Madison, WI, USA) and SuperScript RNase H-Reverse Transcriptase (Promega, Madison, WI, USA) at $42^{\circ} \mathrm{C}$ for $1 \mathrm{~h}$. The mRNAs of genes of interest were amplified for 35 cycles from $10 \%$ of the total first strand CDNA. PCR primers are described in Table 1. The following primer pairs were used to amplify cDNA for cyclin A, cycline E, DHFR or GAPDH respectively. PCR products were analyzed by agarose gel electrophoresis and visualized by ethidium bromide.

\section{Immunoblotting}

Cellular lysates were prepared by suspending $3 \times 10^{5}$ cells $/ 35 \mathrm{~mm}$ dish in $30 \mathrm{ml}$ of lysis buffer [ $50 \mathrm{mM}$ Tris, 150 $\mathrm{mM} \mathrm{NaCl}, 5 \mathrm{mM}$ EDTA, $1 \mathrm{mM}$ DTT, $0.5 \% \mathrm{NP}-40,100 \mathrm{mM}$ phenylmethylsulfonyl fluoride, $20 \mathrm{mM}$ aprotinin, and 20 $\mathrm{mM}$ leupeptin, adjusted to ( $\mathrm{pH}$ 8.0)]. The cells were disrupted and extracted at $4^{\circ} \mathrm{C}$ for $30 \mathrm{~min}$. The proteins were electrotransferred to Immobilon P-membranes (Millipore Corporation, MA, USA). Detection of specific proteins was carried out with an enhanced chemiluminescence Western blotting kit following the manufacturer's instructions (Amersham, NJ, USA).

Table 1. Primer sequences used for RT-PCR of cyclin A, cyclin E and DHFR expression

\begin{tabular}{|c|c|c|}
\hline $\begin{array}{c}\text { Cyclin A } \\
\text { (466bp) }\end{array}$ & 5'-TCCAAGAGGACCAGGAGAATATCA-3' & sense \\
\hline & 5'-TCCTCATGGTAGTCTGGTACTTCA-3' & antisense \\
\hline \multirow[t]{2}{*}{$\begin{array}{l}\text { Cyclin E } \\
(474 \mathrm{bp})\end{array}$} & 5'-AGTTCTCGGCTCGCTCCAGGAAGA-3' & sense \\
\hline & 5'-TCTTGTGTCGCCATATACCGGTCA-3' & antisense \\
\hline \multirow[t]{2}{*}{$\begin{array}{c}\text { DHFR } \\
(300 \mathrm{bp})\end{array}$} & $5^{\prime}$-CAGAGAACTCAAGGAACCTCCAC-3' & sense \\
\hline & 5'-TTAATGCCTTTCTCCTCCTGGAC-3' & antisense \\
\hline $\begin{array}{l}\text { GAPDH } \\
(983 b p)\end{array}$ & 5'-TCGGAGTCAACGGATTTGG-3' & sense \\
\hline & 5'AACTGTGAGGAGGGGAGATTCAG-3' & antisense \\
\hline
\end{tabular}

Ten microliter aliquots of each $50 \mathrm{ul} \mathrm{PCR}$ product was resolved on a $2 \%$ agarose gel and the gel was stained with ethidium bromide. DNA fragments were visualized on a UV-illuminator.

\section{Transfection and reporter gene assays.}

Cells were plated at $3 \times 10^{5}$ cells per $60 \mathrm{~mm}$-diameter culture dishes, and transfection was performed by calcium phosphate coprecipitation method as described previously [5], or with Lipofectamine ${ }^{\mathrm{TM}}$ (molar ratio DNA:lipid=1:3) (Gibco BRL, NY, USA) according to manufacturer's instruction. Each transfection contained a total of $4.8 \mu \mathrm{g}$ of DNA, including $2.4 \mathrm{\mu g}$ of reporter plasmid and $2.4 \mathrm{\mu g}$ of salmon sperm carrier DNA per dish, for calcium phosphate coprecipitation method, and $2 \mu \mathrm{g}$ DNA per dish in the Lipofectamine. To analyze luciferase expression, cells were washed twice with PBS and lysed with $200 \mathrm{ml}$ of 1 $\times$ Reporter lysis buffer (Promega, Madison, WI, USA). Each lysate $(50 \mu l)$ was examined for luciferase activity.

\section{Antibodies}

Primary antibodies to cyclin A (C-19), cyclin E (HE111), cyclin B1 (GNS1), cdc25C (C-20), Sp1 (Pep-2), HDAC1 (H-51) and actin (C-11) were purchased from Santa Cruz Biotechnology.

\section{Results}

TSA blocks cell growth and proliferation at G2/M phase of human osteosarcoma, U2OS and human cervical carcinoma, C33A cells

Proliferation of both U2OS and C33A cells were significantly inhibited by TSA during 2 days. After addition of $100 \mathrm{nM}$ TSA, U2OS and C33A cells underwent a remarkable time-dependent morphological change, U2OS cells showed cytoplasmatic extensions and elongation and C33A cells showed rounding shape (Fig. 1). To confirm the effect of TSA on cell cycle, FACS analysis was performed. After treatment for $24 \mathrm{~h}$ culture with various concentrations of TSA ranging $0,10,50$ and $100 \mathrm{nM}$, the population of U2OS cells in G2/M phase was increased from $15 \%$ to $66.8 \%$ by $100 \mathrm{nM}$ TSA, while that in G1 phase was decreased from $61.6 \%$ to $10 \%$ at this content (Fig. 2A). FACS analysis results showed that the TSA treated cells progressed through $\mathrm{G} 1 / \mathrm{S}$ phase, but then encountered a $\mathrm{G} 2 / \mathrm{M}$ phase block. In the case of $\mathrm{C} 33 \mathrm{~A}$ cells, cell population increased from $17.1 \%$ to $46.5 \%$ in $\mathrm{G} 2 / \mathrm{M}$ phase and remained accumulation of that in G1 after $24 \mathrm{~h}$ of treatment with $100 \mathrm{nM}$ TSA (Fig. 2B). 


\section{Culture time}

$0 \mathrm{hr}$
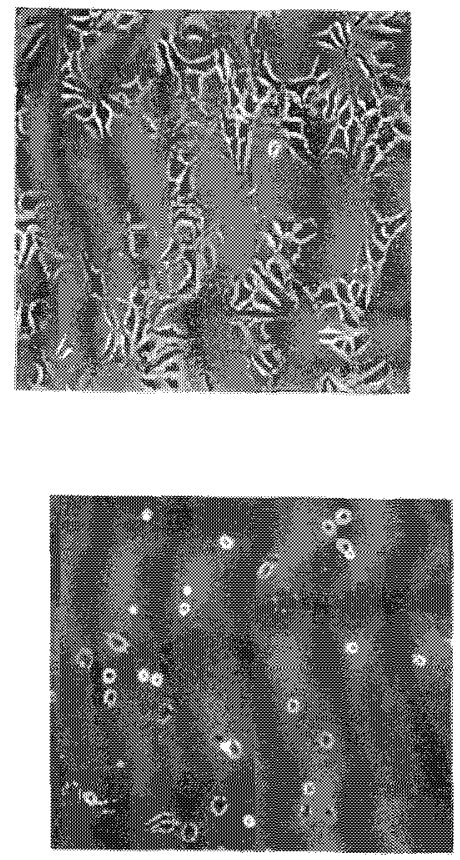

$24 \mathrm{hr}$

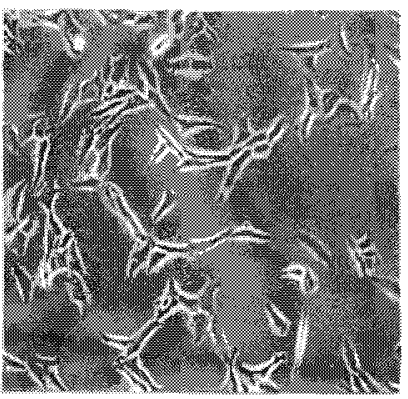

U20S

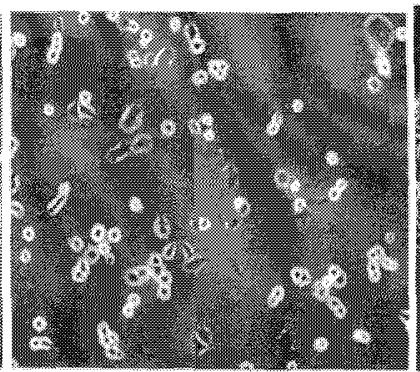

C33A

Fig. 1. Morphological change of U2OS and C33A cells by TSA treatment.

U2OS and C33A cells were grown in culture dishes in the presence of TSA $(100 \mathrm{ng} / \mathrm{ml} ; 24 \mathrm{~h})$ and then followed for 2 days

\section{Effect of TSA on the expression of cell cycle regulators}

We examined the effect of TSA on the protein expression of various cell cycle regulators in U2OS and C33A cell lines. The dose dependent effect of TSA on the expression of various cell cycle regulators at the protein levels is shown in Figure 3. Western blot analysis demonstrated that TSA enhanced the protein expression of cyclin $\mathrm{E}$ in $\mathrm{U} 2 \mathrm{OS}$ and C33A cells, while it reduced the expression of cyclin A, cyclin B, and cdc25C proteins in U2OS cells. However, the protein expression of cyclin $B$ and $c d c 25 C$ were not altered, whereas expression of cyclin A decreased by TSA in C33A cells. Thus, the expression changes of cyclin A, cyclin B and cdc25C by TSA in the U2OS cells may attribute to a block in cell cycle progression. On the other hand, TSA did not affect the protein expression of cyclin $B$ and cdc25C in C33A cells. No change was observed in the expression of Sp1 and HDAC1 protein in both of U2OS and $\mathrm{C} 33 \mathrm{~A}$ cells.
TSA significantly increases the dhfr and cyclin $E$ mRNA level but decrease cyclin A in U2OS cells.

We examined the effects of TSA on mRNA levels of $d h f r$ and cell cycle-regulated genes including cyclin A and cyclin E. RT-PCR assays were performed to examine changes of dhfr, cyclin $\mathrm{E}$ and cyclin A mRNA expression which observed at $24 \mathrm{~h}$ after TSA treatment (Fig. 4). TSA treatment $(100 \mathrm{nM})$ led to a significant induction of dhfr and slight induction cyclin E mRNA expression in U2OS cells but no change in C33A cells. In contrast, the mRNA level of cyclin A was decreased in U2OS cells whereas expression of dhfr and cyclin $\mathrm{E}$ concomitantly increased after TSA treatment. In C33A cells, the same treatment did not affect the level of cyclin A expression. The mRNA levels of cyclin $E$ and cyclin A were consistent with the results of protein expression level in U2OS cells (Fig. 3), We are found down-regulated gene expression by TCA in endogenous cell cycle proteins 

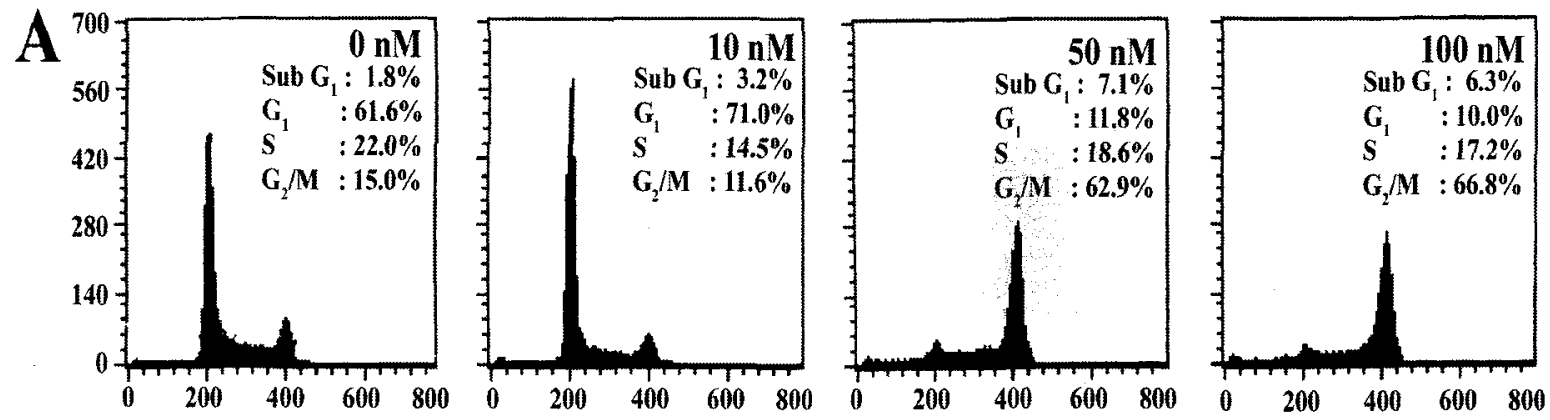

U2OS
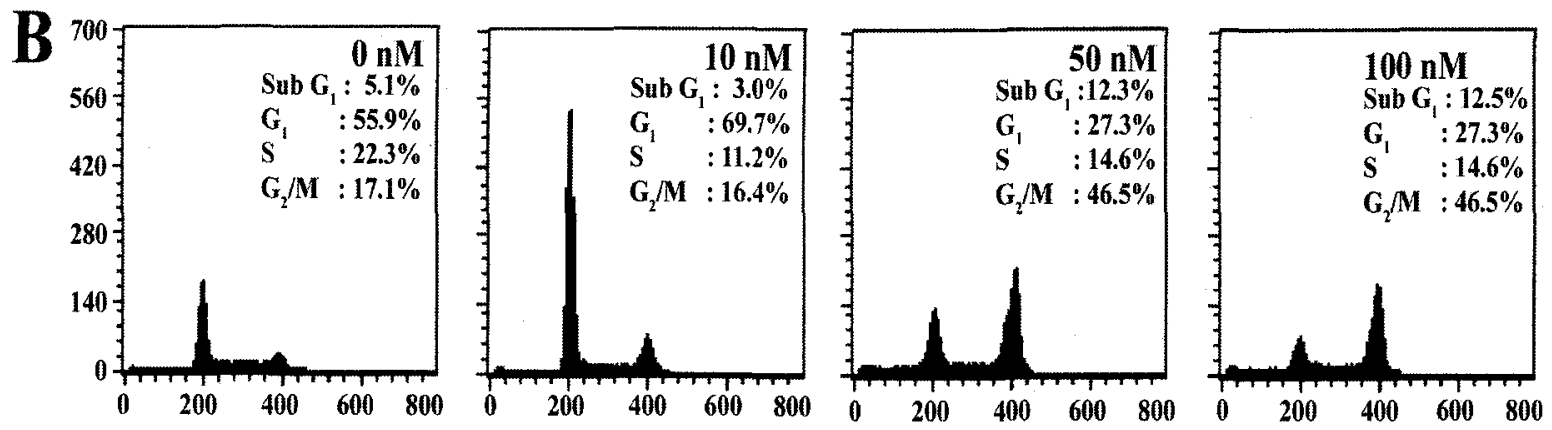

C33A

Fig. 2. Effect of TSA on cell cycle distributions in U2OS and C33A cells.

U2OS and C33A cell lines were cultured in the presence of 0, 10,50 and $100 \mathrm{nM}$ TSA for $24 \mathrm{~h}$. The DNA content of cells was analyzed by a FACScan flow cytometer. Data were confirmed in three independent experiments.

Differential sensitivity of the dhfr $\mathrm{Sp} 1$ sites to TSA in U2OS and C33A cells.

In contrast to the other E2F-dependent promoters studied in Figure 3 and 4 (e.g., cyclin E, cyclin A, and cdc25C), dhfr is unique in that it contains binding sites for Sp1. To investigate the role of $\mathrm{E} 2 \mathrm{~F}$ and $\mathrm{Sp} 1$ in $d h f r$ transcription to the sensitivity of TSA, we used a series of model promoters linked to luciferase reporter genes. Schematics of the wild-type and mutated dhfr-luciferase reporter constructs containing Sp1 and E2F elements of the wild-type position are shown in Figure 5. Cells were transfected with luciferase reporter plasmid containing the wild-type promoter (dhfr-wt-luc), the four upstream Sp1 sites only (dhfr-Sp1-luc), or two overlapping and inverted E2F sites only (dhfr-E2F-luc) and then treated with TSA at $100 \mathrm{nM}$ for $24 \mathrm{~h}$. Although these reporters expressed relatively low levels of luciferase activity when transiently expressed in log phase cells, TSA treatment led to about 14 -fold more activation of transcriptional activity of containing the re- iterated $d h f-S p 1$ sites and even the dhfr-WT promoter exhibited 10-fold activation of transcriptional activity. Otherwise, two overlapping and inverted dhfr-E2F sites promoter showed low basal activity and only a 1.3-fold enhancement was observed in cells treated with TSA (Fig $6 \mathrm{~A})$. These results suggested that the Sp1 sites were responsible for the majority of dhfr promoter activity, and that the dhfr promoter was negatively regulated by TSA-senstive HDAC activity in U2OS cells. These data also indicated that $\mathrm{E} 2 \mathrm{~F}$ acts to repress Sp1-dependent transcription. In contrast to U2OS cells, the effect of TSA on the activation of $d h f r$ promoter was marginal in C33A cells. Figure $6 \mathrm{~B}$ showed that Luciferase activity increased 1.8 fold in C33A with dhfr-Sp1 and dhfr-WT promoter cells but dhfr-E2F promoter did not affect the luciferase activity by TSA. To examine the dhfr promoter specificity of TSA regulation, pGL3-Basic reporter plasmids was tested for TSA regulation. Transcriptional activity of pGL3-Basic was not affected by treatment with TSA, suggesting that this 
regulation is promoter specific (data not shown)

HDAC activity is required for only $S p 1$ to repress DHFR gene expression in standard condition

We examined the ability of Sp1 to recruit HDAC1. U2OS and C33A cells were transfected with ahfr-Sp1-luc or dhfr-E2F-luc together with pCMV-Sp1, pCMV-E2F1, pCMV-DP1, or pCMV-HDAC-Flag and we analyzed repression and activation of dhfr transcriptional activity. HDAC1 alone had over 2.5-fold repressive effect on the dhfr-Sp1 promoter activity by transient transfection, while Sp1 expression increased about 8-folds of the dhfr-Sp1 promoter activity in U2OS cells (Fig. 7A). On the other hand, Sp1 expression increased dhfr-Sp1 promoter activity only 2-3 fold in C33A cells, while HDAC1 expression did not changed the promoter activity (Fig. 7C). These results showed that $\mathrm{HDAC1}$ can mediate Sp1 transcriptional activity of the dhfr promoter in $\mathrm{U} 2 \mathrm{OS}$ cells. Otherwise, when the dhfr-E2F reporter was cotransfected with expression vectors for E2F1 and DP1, luciferase activity of thfr-E2F increased about 2.7-fold in U2OS cells, showing that the con-

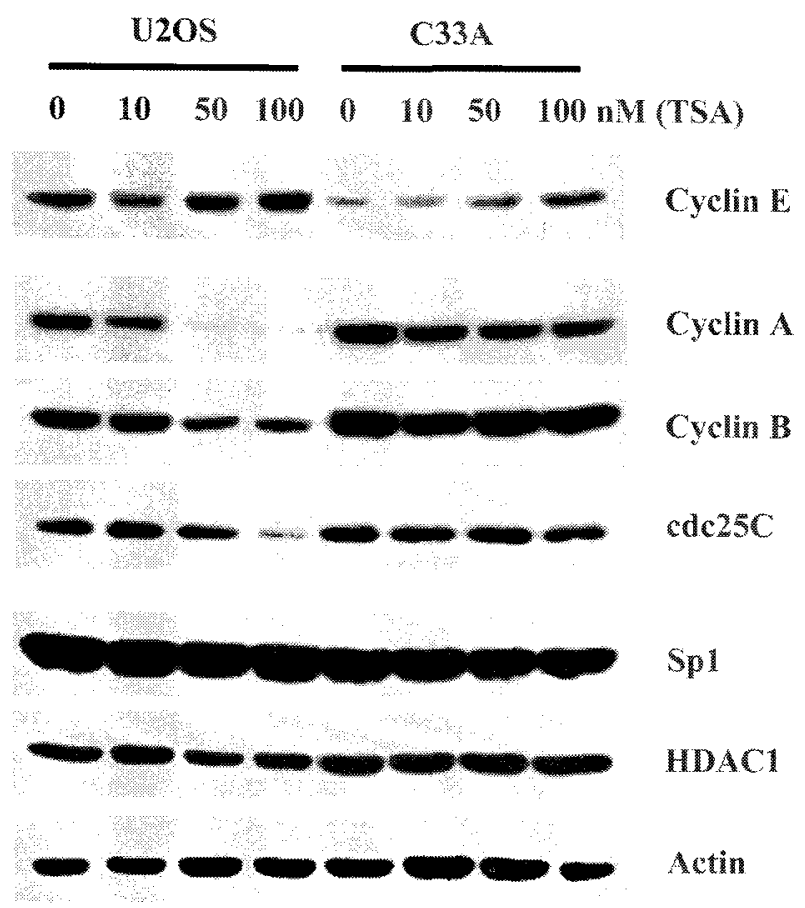

Fig. 3. Effect of trichostatin A on the expression of cell cycle regulatory proteins in $\mathrm{U} 2 \mathrm{OS}$ and C33A cells.

U2OS and C33A cells were treated with $0,10,50$ and $100 \mathrm{nM}$ TSA for $24 \mathrm{~h}$. Changes in the amounts of the endogenous cell cycle proteins were analyzed by Western blotting. struct was responsive to E2F. However, dhfr-E2F promoters containing only two overlapping and inverted E2F binding site had no effect on the level of luciferase activity by $\mathrm{HDAC1}$, suggesting that $\mathrm{HDAC1}$ binds to Sp1 than major factor, E2F in the regulation of the dhfr promoter in U2OS cells, dhfr promoter activation appears to require Sp1 elements (Fig. 7B). On the other hand, in Rb null C33A cells, the luciferase activity of cotransfected dhfr-E2F reporter with E2F1 and DP1 significantly increased over 4.5 fold but not changed by HDAC1 expression (Fig. TD). In support of this interpretation, others have shown that ectopic expression of $\mathrm{Rb}$ from a tetracycline-regulated promoter for $24 \mathrm{~h}$ down-regulates dhfr transcription in cycling U2OS cells and this inhibition is relieved by TSA [40]. We also examined whether the $\mathrm{Rb}$ affects the transcriptional regulation mediated by Sp1/HDAC1 complexes through dhfr-Sp1 site. The expression of $\mathrm{Rb}$ did not changed the dhfr-Sp1 promoter activity suggesting that in combination with $\mathrm{Sp} 1, \mathrm{HDACl}$ and $\mathrm{Rb}$ in dhfr-Sp1 site may not cooperate the transcription in at least U2OS cells (data not shown). The expression levels of Sp1, E2F, DP1 and Flag-tagged HDAC1 were monitored by western blot analysis with the antibody for $\mathrm{Sp} 1$ and the Flag-specific antibody for HDAC1 (data not shown).

\section{Discussion}

The promoter of the dihydrofolate reductase (dhfr) gene,

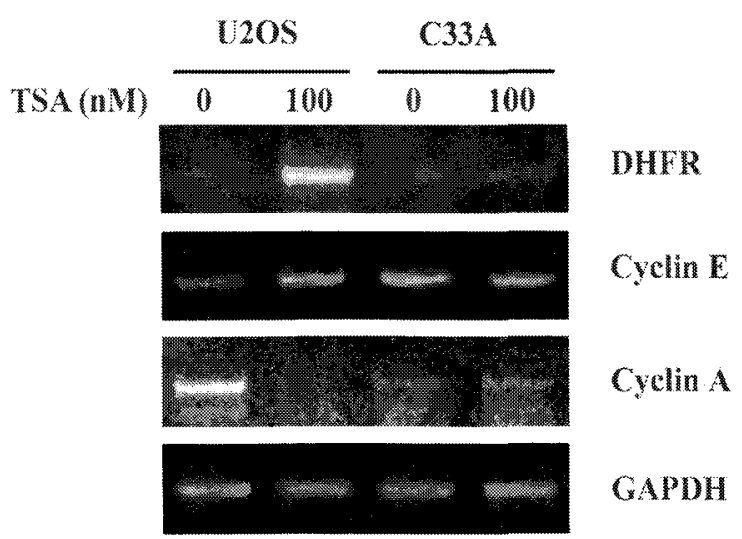

Fig. 4. TSA significantly induced dhfr and cyclin E mRNA expression and decresed cyclin A mRNA expression in U2OS but not C33A cells.

U2OS and C33A cells were treated with $100 \mathrm{nM}$ TSA for $24 \mathrm{~h}$. Changes in the amounts of the endogenous cell cycle mRNA were analyzed by RT-PCR. 


$$
\text { DHFR-WT-luc }
$$

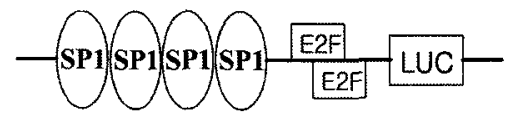

DHFR-Spl-luc

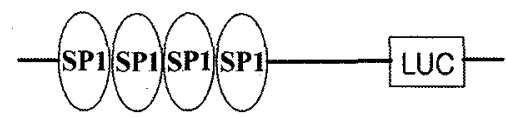

DHFR-E2F-luc

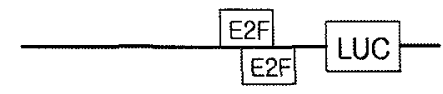

Fig, 5. DHFR-luciferase promoter constructs.

We used a series of model promoters linked to luciferase reporter gene, pGL3-Basic (Promega, USA). The pGL3-DHFR-WT reporter plasmid reporter contains $230 \mathrm{bp}$ of upstream sequence of the $d h f r$ promoter that includes the transcription start site, the overlapping E2F elements, and the Sp1 binding sites (GC boxes I-IV). The pGL3-DHFR-Sp1 luciferase reporter includes nucleotides -230 to -85 , which contain GC boxes $I$ to IV, but not the E2F sites. The pGL3-DHFR-E2F luciferase reporter contains the two overlapping E2F sites alone. which has been well characterized in hamster, mouse, and human, contains Sp1 and E2F response elements in the vicinity of its transcription initiation region [18]. The basal transcription of this gene relies on the presence of these sites, because the position of the E2F site influences the transcription initiation position, and because the absence of functional Sp1 protein or Sp1-binding sites in the promoter abolishes transcription of dhfr gene. Moreover, other experiment showed that the E2F site of the dhfr promoter is involved in promoter silencing in serum-starved conditions, whereas serum responsiveness relies on the Sp1 sites [2]. However, assigning specific roles for Sp1 and E2F in the regulation of $d h f r$ gene expression has generated considerable debate.

In the present study, TSA make activated the promoter activity of $d h f r-W T$ and $d h f r-S p 1$ luciferase reporter plasmids which has four Sp1 sites and also TSA induced the dhfr mRNA in U2OS cells, although weak activity responsed, showed less than a two fold increase in promoter activity in $\mathrm{C} 33 \mathrm{~A}$ cells. On the other hand, we also

A

DHIR-WT' $=$
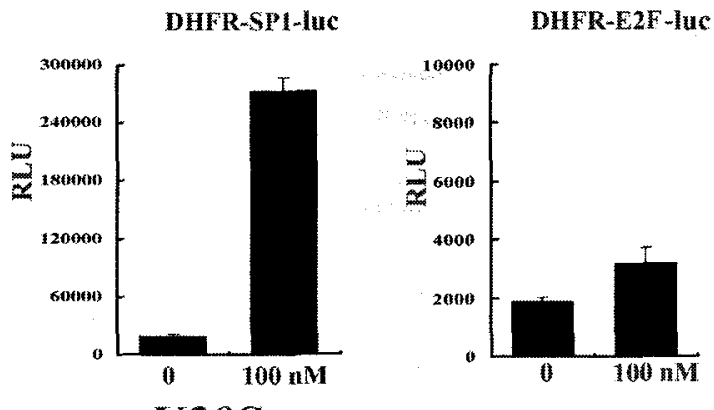

B

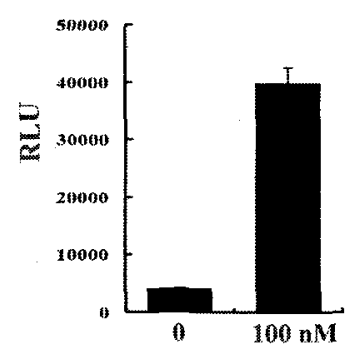

U20S

DHFR-WT -luc
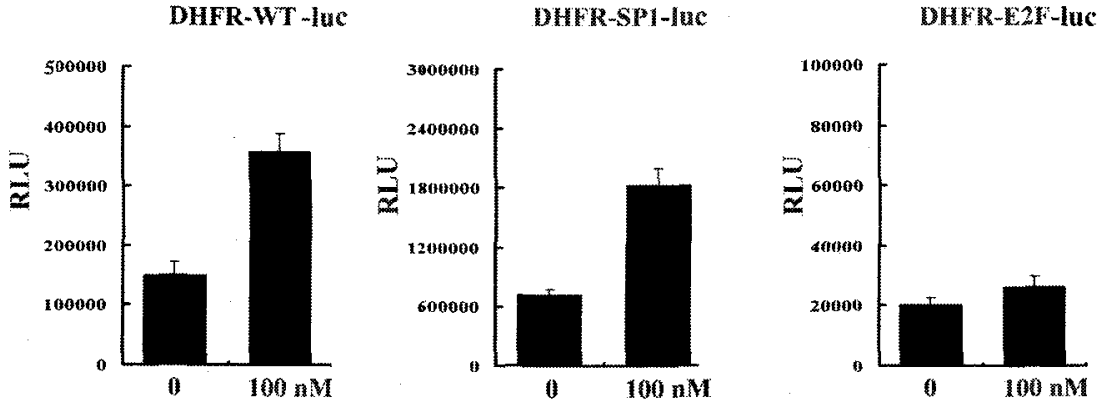

C33A

Fig. 6. Transient expression assays to examine the transcriptional dhfr promoter by TSA.

U2OS and C33A cells were transfected with luciferase reporter genes dhfr-WT-luc, dhfr-Sp1-luc, and dhfr-E2F-luc and incubated with or without TSA. After $24 \mathrm{~h}$ treatment, cells were harvested and luciferase assays were performed. Data represent means and standard deviations from three independent experiments. 


\section{U20S}

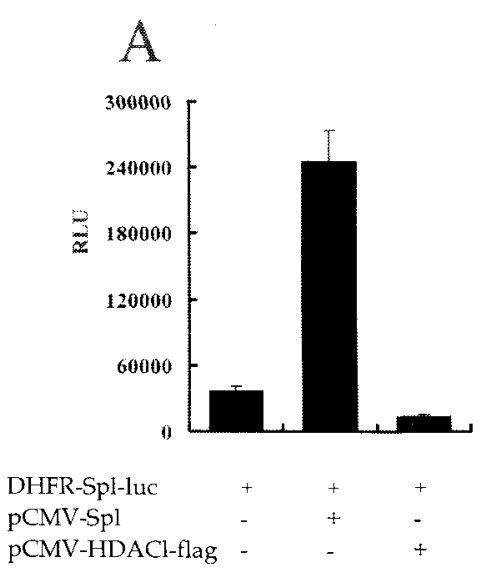

$\mathrm{B}$

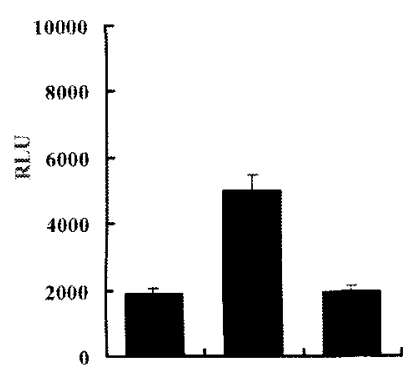

DHFR-E2F-luc PCMV-E2F1/DP1 pCMV-HDACl-flag - $\quad-\quad+$

\section{C33A}

C

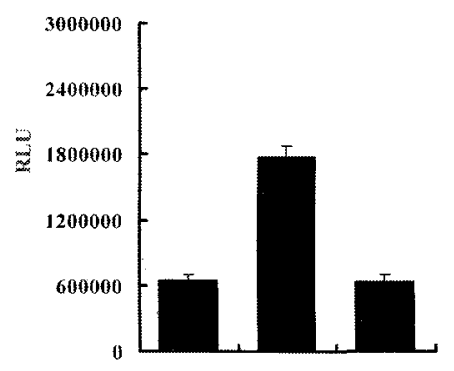

$\begin{array}{llll}\text { DHFR-Spl-luc } & + & + & + \\ \text { pCMV-Spl } & - & + & - \\ \text { pCMV-HDACl-flag } & - & - & +\end{array}$
$\mathrm{D}$

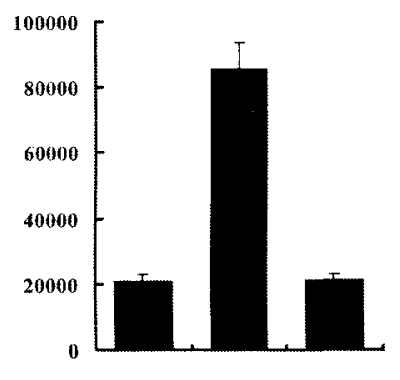

DHFR-E2F-luc $++\quad+\quad+$

$\begin{array}{llll}\text { PCMV-E2F1/DP1 } & - & + & - \\ \text { pCMV-HDACl-flag } & - & - & +\end{array}$

Fig. 7. HDAC1 mediate transcriptional repression through dhfr Sp1 binding sites.

U2OS and C33A Cells were transfected with dhfr-Sp1-luc or dhfr-E2F-luc together with pCMV-Sp1, pCMV-E2F1, pCMV-DP1, or pCMV-HDAC-Flag. Luciferase activity in whole-cell extracts prepared from transfected cells was measured. Data are means and standard deviations from three independent experiments.

observed that mRNA level of cyclin E regulated by Sp1 was profoundly increased by TSA in U2OS but not C33A cells. These data showed that Sp1 is involved transcriptional activation of the alhfr in response to TSA in U2OS cells. These results also suggested that TSA action is specific to U2OS cells and further suggested a mechanism whereby HDACs is involved in dhfr repression in U2OS cells. There was a reporter that demonstrating the regulation of dhfr promoter by TSA, in which the role of Sp1 remained to be elucidated [5]. These results were consistent with the Sp1 site effects of HDAC inhibitors on the regulation of the gene expression. Sp1 plays a key role in the activation of a large number of genes, including housekeeping and cell-cycle regulated genes, containing upstream GC Box promoter elements. Furthermore, the Sp1 site has been shown to be responsible for TSA-induced expression of the p21 gene promoters [33]. On the other hand, reported that Sp1 could be a target for HDAC1-mediated transcriptional repression. Moreover, Sp1 was found to make a complex directly with the Histone Acetyl Transferase (HAT) and HDAC1 (15Doetzlhofer et al., 1999).

Finally, results of RT-PCR analysis indicated that in only U2OS cells, expression of G1 phase genes such as dhfr and cyclin E, which contain Sp1 and E2F sites in their pro- 
moters, were activated by TSA treatment, but $S$ genes such as cyclin $\mathrm{A}$ were repressed. In several model, $\mathrm{Rb}$ repressed genes normally activated during G1 such as cyclin E, thymidine kinase, and dihydrofolate reductase as well as the $S$ phase genes cyclin $A$ and cdc2 [42]. Based on the above results, we suggested that cooperation of Rb-HDAC activity may be required for $\mathrm{Rb}$ to regulate the $d h f r$ and cyclin $\mathrm{E}$ gene in cell cycle.

In summary, the results compared the effects of HDAC inhibitor on the transcription of cell cycle related gene in both of U2OS and C33A cells. We showed that TSA, a inhibitor of HDAC dramatically induced transcription of $d h f r$ in U2OS cells, but not in C33A cells and Sp1 plays a crucial role in this regulation. A series of mutational analyses of the dhfr promoter have revealed that the main TSA response element is the Sp1 site in U2OS cells. These findings explain one mechanism of promoter silencing of the dhfr gene through Sp1 site in U2OS cell line. We also observed that expression of cyclin A was profoundly suppressed by TSA, despite the presence of Sp1 and E2F elements similar to dhfr promoter. Ectopic expression of E2F1 represses promoter activity of human telomerase reverse transcriptase in tumor cells, while it activates the promoter in normalhuman somatic cells [40]. Differences in the number and the arrangement of binding motifs might influence the factors recruited to the promoter, their mutual interactions, and thus entire promoter activity.

\section{References}

1. Black, A. R., Jensen, D., Lin, S. Y. and Azizkhan, J. C. 1999. Growth/cell cycle regulation of Sp1 phosphorylation. J. Biol. Chem 274(3), 1207-1215.

2. Blake, M. C. and Azizkhan, J. C. 1989. Transcription factor $\mathrm{E} 2 \mathrm{~F}$ is required for efficient expression of the hamster dihydrofolate reductase gene in vitro and in vivo. Mol. Cell. Biol. 9(11), 4994-5002.

3. Blake, M. C., Jambou, R. C., Swick, A. G., Kahn, J. W. and Azizkhan, J. C. 1990. Transcriptional initiation is controlled by upstream GC-box interactions in a TATA-less promoter. Mol. Cell. Biol. 10(12), 6632-6641.

4. Brehm, A., Miska, E. A., McCance, D. J., Reid, J. L., Bannister, A. J. and Kouzarides, T. 1998. Retinoblastoma protein recruits histone deacetylase to repress transcription. Nature 391 (6667), 597-601.

5. Chang, Y. C., Illenye, S. and Heintz, N. H. 2001. Cooperation of E2F-p130 and Sp1-pRb complexes in repression of the Chinese hamster dhfr gene. Mol. Cell. Biol. 21(4), 1121-1131.
6. Ciudad, C. J., Morris, A. E., Jeng, C. and Chasin, L. A. 1992. Point mutational analysis of the hamster dihydrofolate reductase minimum promoter. J. Biol. Chem. 267(6), 3650-3656.

7. DeCaprio, J. A., Ludlow, J. W., Lynch, D., Furukawa, Y., Griffin, J., Piwnica-Worms, H., Huang, C. M. and Livingston, D. M. 1989. The product of the retinoblastoma susceptibility gene has properties of a cell cycle regulatory element. Cell 58(6), 1085-1095.

8. Doetzlhofer, A., Rotheneder, H., Lagger, G., Koranda, M., Kurtev, V., Brosch, G., Wintersberger, E. and Seiser, C. 1999. Histone deacetylase 1 can repress transcription by binding to Sp1. Mol. Cell. Biol. 19, 5504-5511.

9. Eickhoff, B., Ruller, S., Laue, T., Kohler, G., Stahl, C., Schlaak, M. and van der Bosch, J. 2000. Trichostatin A modulates expression of p21waf1/cip1, Bcl-xL, ID1, ID2, ID3, CRAB2, GATA-2, hsp86 and TFIID/TAFII31 mRNA in human lung adenocarcinoma cells. Biol. Chem 381(2), 107-112.

10. Farnham, P. J. and Schimke, R. T. 1985. Transcriptional regulation of mouse dihydrofolate reductase in the cell cycle. J. Biol. Chem 260(12), 7675-7680.

11. Farnham, P. J. and Schimke, R. T. 1986. Murine dihydrofolate reductase transcripts through the cell cycle. $\mathrm{Mol}$. Cell. Biol. 6(2), 365-371.

12. Ferrara, F. F., Fazi, F., Bianchini, A., Padula, F., Gelmetti, V., Minucci, S., Mancini, M., Pelicci, P. G., Lo Coco, F. and Nervi, C. 2001. Histone deacetylase-targeted treatment restores retinoic acid signaling and differentiation in acute myeloid leukemia. Cancer Res. 61(1), 2-7.

13. Finnin, M. S., Donigian, J. R., Cohen, A., Richon, V. M., Rifkind, R. A., Marks, P. A. and Breslow Rand Pavletich, N. P. 1999. Structures of a histone deacetylase homologue bound to the TSA and SAHA inhibitors. Nature 401, 188-193.

14. Han, J. W., Ahn, S. H., Kim, Y. K., Bae, G. U., Yoon, J. W., Hong, S., Lee, H. Y., Lee, Y. W. and Lee, H. W. 2001. Activation of p21(WAF1/Cip1) transcription through Sp1 sites by histone deacetylase inhibitor apicidin: involvement of protein kinaseC. J. Biol. Chem 276(45), 42084-42090.

15. Heinzel, T., Lavinsky, R. M., Mullen, T. M., Soderstrom, M., Laherty, C. D., Torchia, J., Yang, W. M., Brard, G., Ngo, S. D., Davie, J. R., Seto, E., Eisenman, R. N., Rose, D. W., Glass, C. K. and Rosenfeld, M. G. 1997. A complex containing $\mathrm{N}-\mathrm{CoR}, \mathrm{mSin} 3$ and histone deacetylase mediates transcriptional repression. Nature 387(6628), 43-48.

16. Hendrickson, S. L., Wu, J. S. and Johnson, L. F. 1980. Cell cycle regulation of dihydrofolate reductase mRNA metabolism in mouse fibroblasts. Proc. Natl. Acad. Sci. 77(9), 5140-5144.

17. Huang, L., Sowa, Y., Sakai, T. and Pardee, A. B. 2000. Activation of the p21WAF1/CIP1 promoter independent of $\mathrm{p} 53$ by the histone deacetylase inhibitor suberoylanilide hydroxamic acid (SAHA) through the Sp1 sites. Oncogene 19(50), 5712-5719.

18. Jensen, D. E., Black, A. R., Swick, A.G. and Azizkhan, J. 
C. 1997. Distinct roles for Sp1 and E2F sites in the growth/cell cycle regulation of the DHFR promoter. I. Cell. Biochem 67(1), 24-31.

19. Johnson, L. F., Fuhrman, C. L. and Wiedemann, L. M. 1978. Regulation of dihydrofolate reductase gene expression in mouse fibroblasts during the transition from the resting to growing state. J. Cell. Physiol 97(Suppl 1), 397-306.

20. Johnstone, R. W. 2002. Histone-deacetylase inhibitors. Nat. Rev. Drug Discov. 1(4), 287-299.

21. Kao, H. Y., Ordentlich, P., Koyano-Nakagawa, N., Tang, Z., Downes, M., Kintner, C. R., Evans, R. M. and Kadesch, T. 1998. A histone deacetylase corepressor complex regulates the Notch signal transductionpathway. Genes Dev. 12(15), 2269-2277.

22. Laherty, C. D., Yang, W. M., Sun, J. M., Davie, J. R., Seto, E., Eisenman, R. N. 1997. Histone deacetylases associated with the $\mathrm{mSin} 3$ corepressor mediate mad transcriptional repression. Cell 89(3), 349-356.

23. Marks, P. A., Richon, V. M., Breslow, R. and Rifkind, R. A. 2001. Histone deacetylase inhibitors as new cancer drugs. Curr. Opin. Oncol. 13(6), 477-483.

24. Marks, P., Rifkind, R. A., Richon, V. M., Breslow, R., Miller, T. and Kelly, W. K. 2001. Histone deacetylases and cancer: causes and therapies. Nat. Rev. Cancer 1(3), 194-202.

25. Means, A. L., Slansky, J. E., McMahon, S. L., Knuth, M. W. and Farnham, P. J. 1992. The HIP1 binding site is required for growth regulation of the dihydrofolate reductase gene promoter. Mol. Cell. Biol. 12(3). 1054-1063.

26. Murata, Y., Kim, H. G., Rogers, K. T., Udvadia, A. J. and Horowitz, J. M. 1994. Negative regulation of Sp1 trans-activation is correlated with the binding ofcellular proteins to theamino terminus of the Sp1 trans-activation domain. J. Biol. Chem. 269(32), 20674-20681.

27. Nakano, K., Mizuno, T., Sowa, Y., Orita, T., Yoshino, T., Okuyama, Y., Fujita, T., Ohtani-Fujita, N., Matsukawa, Y., Tokino,T., Yamagishi, H., Oka, T., Nomura, H. and Sakai, T. 1997. Butyrate activates the WAF1/Cip1 gene promoter through $\mathrm{Sp1}$ sites in a p53-negative human colon cancer cell line. J. Biol. Chem. 272(35), 22199-22206.

28. $\mathrm{Ng}, \mathrm{H} . \mathrm{H}$. and Bird, A. 1999. DNA methylation and chromatin modification. Curr. Opin. Genet. Dev. 9(2), 158-163.

29. Noe, V., Chen, C., Alemany, C., Nicolas, M., Caragol, I., Chasin, L. A. and Ciudad, C. J. 1997. Cell-growth regulation of the hamster dihydrofolate reductase gene promoter by transcription factor Sp1. Eur. J. Biochem. 249(1), 13-20.

30. Saito, A., Yamashita, T., Mariko, Y., Nosaka, Y., Tsuchiya, K., Ando, T., Suzuki, T., Tsuruo, T. and Nakanishi, O, 1999. A synthetic inhibitor of histone deacetylase, MS-27-275, with marked in vivo antitumor activity against human tumors. Proc. Natl. Acad. Sci. 96(8), 4592-4597.
31. Santiago, C., Collins, M. and Johnson, L. F. 1984. In vitro and in vivo analysis of the control of dihydrofolate reductase gene transcription in serum-stimulated mouse fibroblasts. J. Cell. Physiol, 118(1), 79-86.

32. Slansky, J. E., Li, Y., Kaelin, W. G. and Farnham, P. J. 1993. A protein synthesis-dependent increase in E2F1 mRNA correlates with growth regulation of the dihydrofolate reductase promoter. Mol. Cell. Biol. 13(3), 1610-1618.

33. Sowa, Y., Orita, T., Minamikawa, S., Nakano, K., Mizuno, T., Nomura, H. and Sakai, T. 1997. Histone deacetylase inhibitor activates the WAF1/Cip1 gene promoter through the Sp1 sites. Biochem. Biophys. Res. Commun. 241(1), $142-150$.

34. Vigushin, D. M. and Coombes, R. C. 2002. Histone deacetylase inhibitors in cancer treatment. Anticancer Drugs 13(1), 1-13.

35. Vigushin, D. M., Ali, S., Pace, P. E., Mirsaidi, N., Ito, K., Adcock, I. and Coombes, R. C. 2001. Trichostatin A is a histone deacetylase inhibitor with potent antitumor activity against breast cancer in vivo. Clin. Cancer Res. 7(4), 971-976

36. Wade, M., Kowalik, T. F., Mudryj, M., Huang, E. S. and Azizkhan, J. C. 1992. E2F mediates dihydrofolate reductase promoter activation and multiprotein complex formation in human cytomegalovirus infection. Mol. Cell. Biol. 12(10), 4364-4374.

37. Wade, P. A., Pruss, D. and Wolffe, A. P. 1997. Histone acetylation: chromatin in action. Trends Biochem. Sci. 22(4), 128-132.

38. Wells, J. M., Illenye, S., Magae, J., Wu, C. L. and Heintz, N. H. 1997. Accumulation of E2F-4.DP-1 DNA binding complexes correlates with induction of dhfr gene expression during the G1 to S phase transition. J. Biol. Chem. 272(7), 4483-4492.

39. Wells, J., Held, P., Illenye, S. and Heintz, N. H. 1996. Protein-DNA interactions at the major and minor promoters of the divergently transcribed dhfr and rep3 genes during the Chinese hamster ovary cell cycle. Mol. Cell. Biol. 16(2), 634-647.

40. Won, J., Yim, J. and Kim, T. K. 2002. Opposing regulatory roles of E2F in human telomerase reverse transcriptase (hTERT) gene expression in human tumour and normal somatic cells. FASEB J. 16, 1943-1945.

41. Yoshida, M., Furumai, R., Nishiyama, M., Komatsu, Y., Nishino, N. and Horinouchi, S. 2001. Histone deacetylase as a new target for cancer chemotherapy. Cancer Chemother. Pharmacol. 48(Suppl 1), 20-26.

42. Zhang, H. S., Gavin, M., Dahiya, A., Postigo, A. A., Ma, D., Luo, R. X., Harbour, J. W. and Dean, D. C. 2000. Exit from G1 and $S$ phase of the cell cycle is regulated by repressor complexes containing HDAC-Rb-hSWI/SNF and Rb-hSWI/SNF. Cell 101(1), 79-89. 


\section{초록 : Trichostatin A 처리에 의하 세포주기 조절인자들의 전사활성화 및 불활성화}

백종수 ${ }^{1} \cdot$ 이회경 ${ }^{1} \cdot$ 조영수 $^{2} \cdot$ 김성영 $^{3} \cdot$ 박관규 $^{2} \cdot$ 장영채 ${ }^{*}$

(대구가톨릭대학교 의과대학 병리학교실, ${ }^{1}$ 영남대학교 의과대학 치과학교실, ${ }^{2}$ 동아대학교 생명자원과학 대학 응용생명공학부, ${ }^{3}$ 안동과학대학 식품조리과)

Dihydrofolate reductase (dhfr) promoter에는 전사 인자 Sp1과 E2F가 결합하는 cis-acting 배열을 가지고 있 다. dhfr 유전자의 전사는 세포 주기 G1/S기 동안 최대의 발현을 나타낸다. 또한 Sp1 전사 인자는 dhfr 유전자 발현의 활성화 및 불활성화를 조절하는 다양한 역할에 대한 연구가 보고 되고 있으며, 최근 $\mathrm{Sp1}-\mathrm{Rb}$ 과 E2F4-p130 복합체가 CHOC400 세포에서 dhfr 유전자 발현에 안정한 형태를 형성하여 dhfr 발현을 억제한다는 연구 결과가 보고되었다. 본 연구에서는 $\mathrm{Rb}$-양성 골육종 세포인 U2OS 및 $\mathrm{Rb}$-음성인 자궁경부암 $\mathrm{C} 33 \mathrm{~A}$ 세포에 서 histon deacetylase (HDAC)에 대한 특이적인 저해제인 trichostatin A (TSA)를 처러한 후 체포주기 조절에 중심적 인자들인 dhfr, cyclin E 및 cyclin A의 전사활성에 대한 $\mathrm{HDAC1}$ 의 기능을 조사하였다. $\mathrm{U} 2 \mathrm{OS}$ 및 $\mathrm{C} 33 \mathrm{~A}$ 세포에서 TSA를 처리한 후, dhfr, cyclin E, cyclin A에 대한 mRNA 및 단백질 발현을 조사한 결과 U2OS 세포 특이적으로 dhfr와 cyclin E의 mRNA 발현과 단백질 발현이 크게 중가하였지만, cyclin A의 발현은 감소하였다. $\mathrm{U} 2 \mathrm{OS}$ 세포에서 dhfr promoter construct에 대한 전사활성을 검사한 결과, TSA 처리는 dhfr promoter 영역으로 부터 E2F 결합부위를 제거시킨 DHFR-Sp1-luc를 통하여 dhfr promoter 활성이 약 14배 증가되었다, 그러나 dhfr promoter 영역으로부터 Sp1 결합부위를 제거시킨 DHFR-E2F-luc 영역을 포함하고 있는 promoter 활성은 TSA 처리에 의해 크게 증가되지 않았다. 본 연구에서 이러한 결과는 $\mathrm{HDAC1}$ 이 Sp1을 통하여 dhfr promoter 활성을 제어한다는 사실을 입증하였다. 한편 TSA는 U2OS 세포에서 $\mathrm{HDAC}$ 의 활성을 통해서 세포주기 관련 인자들 가 운데서 $\mathrm{G} 1$ 후기부터 활성화되는 대표적인 인자들인 dhfr과 cyclin E의 발현을 증가시키지만 $\mathrm{G} 2$ 기에서 활성화 되는 대표적인 인자인 cyclin $\mathrm{A}$ 의 발현을 억제하는 상반된 기능을 가지고 있다는 사실을 확인하였다. 